(C) 2021 Geri Pilaca and Alban Nako. This is an open access article licensed under the Creative Commons Attribution-NonCommercial 4.o International License (https://creativecommons.org/licenses/by-nc/4.0/)
\end{abstract}

Received: 4 May 2021 / Accepted: 21 June 2021 / Published: 8 July 2021

\title{
Splitting Apart: How the Soviet-Albanian Relations Came to an End
}

\section{Geri Pilaca}

\author{
Alban Nako \\ Faculty of Law and Social Sciences, \\ Department of Political Science and International Relations, \\ Epoka University, Tirana, Albania
}

DOI: https://doi.org/10.36941/mjss-2021-0o28

\begin{abstract}
Albania was the only Eastern European country to exit from the Warsaw Pact and consequently become diplomatically isolated by its member states by late 1961. Such an event was the result of the continuous accusations exchanged between the Albanian and the Soviet Leaders, primarily between Enver Hoxha and Nikita Khrushchev. In the midst of the turbulent Soviet-Albanian relations, China offered its alliance to Albania which only worsened the situation. This study aims to illustrate how the curve of the AlbanianSoviet partnership changed over time, starting from the Stalin era and finishing with the Khrushchev era. More precisely, this study explains how Khrushchev's decision-making concerning other countries, especially Yugoslavia, pushed the Albanian leaders into changing attitude towards the Soviet Union and make alliances with Mao Zedong.
\end{abstract}

Keywords: Albania, Soviet Union, split, China

\section{Introduction}

The story of the Soviet-Albanian split remains a particular and interesting case study not only because Albania was the second communist state after Yugoslavia to seize all the possible relations with the USSR but also because of the main factors that lead to the disruption of what was seen as very close relations. In fact, before the burst of the first tensions, it was considerate as almost unimaginable for the small Eastern European country to oppose a great power on which it was dependent. However, history has shown that decision-making can change the course of the events. Moreover, the Albanian-Soviet alliance was characterized by ups and downs, proliferating tensions from both sides. Such variations of the relations were generated mainly by external but also by the internal factors which made Albania keep certain attitudes to the Soviet Union's decision-making not only concerning itself but also other countries of the Eastern Bloc.

During the era of Josip Stalin, Albania had close political and economic cooperation with the Soviet Union. Such cooperation was crowned by the large financial aid provided for Albania, which at that time was in extreme poverty, with an underdeveloped agricultural sector and a non-existing industrial sector. Moreover, Albania became attached to the Stalinist doctrine and continued to be faithful to such doctrine until the very end of its communist regime (Fischer, 2007).

However, after the death of Stalin, Nikita Khrushchev's rise into power changed the rules of play 
in the whole Eastern Bloc. It was during Khrushchev's ruling when it was seen the starting of disputes between Albania and the Soviet Union. The factors which contributed to configuring the whole political landscape of the Tirana's dispute with Moscow were three: The rapprochement of Yugoslavia with the Soviet Union, the influence of China, and Khrushchev's harsh measures on Albania by the summer of 1960 .

The delicate relations between Yugoslavia and the Soviet Union had a direct impact on Albania, who at that time, was in difficulty, considering that these two actors had ambiguous intentions regarding the country. On one hand, Yugoslavia had shown attempts to annex Albania and, on the other hand, the Soviet Union was always a constant threat to the integrity of the country and of its domestic political elite. Amid this situation, the Albania political elite would engage in continuous debates with the Soviet Union whenever the latter would show signs of cooperation with Yugoslavia.

Following such a situation, and taking into consideration the survival of the status quo, Albania decided to ally with China. At that time, China was an emerging power which decided to challenge the Soviet Union and to do so it decided to form new alliances with countries such as Albania which was seen also a gate to enter into Europe. The new Sino-Albanian alliance established, heavily impacted the attitude of the Soviet Union who was not in favour of such a thing.

Consequently, during the Bucharest meeting in 1960, the Soviet Union expressed its disapproval for the Sino-Albanian close relations and the defiance that these two countries were making against the Warsaw Pact's line. In this meeting, the tones were raised and it was concluded by the Albanian delegation's abandonment of it. Following the rebellious actions taken by Albania, the Soviet Union decided to take measures, one of which was the organizing of a coup against Hoxha and also cutting the financial aid. (CIA, 1962) Consequently, the Soviet-Albanian tensions would carry out during the Moscow Conference by late 1960, after which, the Soviet Union decided to initiate the measures which would lead to the breaking of the diplomatic relations in Albania in the following year.

This study focuses on the fluctuation of the Soviet-Albanian relations between 1955 and 1961 and the role of China in the middle, by focusing more the disputes that arose during the Khrushchev era by taking into considerations the letters that have been exchanged between the Albanian and Soviet officials and the speeches and dialogues emitted during the meetings held as well other data.

An important source for the breaking down of the Soviet-Albanian split and providing the raw and central information is William S. Griffin's work which provides a contemporary analysis of the event. As a supplementary to Griffith's work, are the records retrieved from the Albanian State Archive as well as the books that were written by Hoxha, and most importantly, is the CIA report on the Soviet-Albania relations during the period 1940-1960.

\section{The Peaceful Soviet-Albanian Relations}

After the disruption of the Soviet-Yugoslavian relations in 1948, Albania would receive much more attention not only diplomatically but also economically from the Soviet Bloc. In September of that same year, the Soviet Union would lay its major influence in Albania, a country that needed economic aid. Consequently, in 1949, 38\% of the Albanian state revenues would come from the financial aids and grants arriving from the Soviet countries. Such aid was provided when the Council for Mutual Economic Assistance (COMECON) was established and in which, Albania became part instantly. Thanks to such financial support, the Albanian economy was experiencing a blooming especially in the industry and mines sectors (Griffith, 1964).

Besides providing help in reconstructing the economy, the Soviet Union would provide Albania with military assistance as well. Consequently, by the end of 1948, there were more than 3000 soviet civilian and military advisors assisting Albania. Moreover, there was a considerable number of Albanian state officials, students, and workers who went in the Soviet Bloc countries for training, education and surely to strengthen the relations among countries even more.

The Soviet support wasn't just an assistance provider but also an assurance that Albania's territorial integrity wouldn't be put into risk by the surrounding countries (Kramer, 2014). The fear 
from a possible annexation by the Yugoslavs would push Enver Hoxha to take harsh measures. Having his back scratched by Stalin, he went on retaliating against Koçi Xoxe, a declared Tito-ist and an imminent threat to the incumbent power within the communist party. Therefore, in 1949, Hoxha followed a method which was present in all the Eastern-Bloc countries, he executed Xoxe as a decedent (CIA, 1962).

The initiation of the purge within the party would provide a clear lead to the full sovietisation of the whole country. Such a process would be quite visible since at the very first beginning there was a construction of several standardized soviet-style buildings, enforcing and proclaiming the sovietisation to its full potential (Pipa, 1990). What is quite interesting about this sovietisation is that it wasn't applied by force from Moscow but in fact, it was an internal development which could be explained by the fact that during that time, Albania being a small and isolated country, was surrounded by neighbours whose inventions were to annex its territories, and because of that, it was necessary to establish alliances with world powers. Therefore, the attention which was given to Albania from its greatest ally and personally from Stalin would turn Hoxha and his reliable party colleagues to one of the most loyal followers of the Stalinist doctrine (Mëhilli, 2017).

However, it seemed that such loyalty to the Stalinist ideology would turn up to be a huge obstacle in embracing Nikita Khrushchev's new ideology in conducting the USSR foreign policy.

\section{The Renewed Soviet-Yugoslavian Relations}

The death of Stalin and Khrushchev's arrival in power would set motions to undesirable outcomes for Albania. In the summer of 1953, The Soviet Union was keen on re-establishing diplomatic relations with Yugoslavia and surely Albania had to follow the Soviet bloc's initiative. However, such an approach would generate a decrease of the Soviet interest in the small satellite, followed by a reduction in financial aid. Such dynamics led to an aggravation of the Albanian economy and consequently, Hoxha made a tactical move by approaching the economic relations with China, which would help Albania develop its agriculture sector. Therefore, it would seem that the first sign of the long chain of the dispute with the Soviet Union would be based on economic aspects (Mëhilli, 2017).

Even though Albania established diplomatic relations with Yugoslavia in December 1953 and continued having a stable relationship in the upcoming years, still there was hesitation and misbelief from the Albanians regarding the Soviet-Yugoslavian approach. Several documents would state that Albania acted in a very cold way regarding its approach with Yugoslavia. Moreover, Khrushchev's initiatives to persuade Albania into improving its relations with Yugoslavia in 1955 were initially faced with some sort of hesitation from the Albanian leaders. As it was documented during that year, the Albanian state was the only soviet satellite to have less cultural, economic and military exchanges with the Yugoslavs compared to the other satellites. Such attitude was duly noted by the Yugoslavs which through the press they emphasized Albania's lack of will for cooperation and the fact that their relations were the worst compared to the other Eastern Bloc countries (Griffith, 1964; Hoxha, 1986; CIA, 1962).

The situation between Albania and Yugoslavia seemed to escalate even further but in fact, Hoxha's visit to Moscow in August $18^{\text {th }} 1955$ apparently would change the course of the events. What can be said is that during that meeting, Khrushchev put a lot of effort to try to alter Hoxha's attitude towards Yugoslavia and to try to improve the relations between these countries. Consequently, after returning from the meeting, Hoxha would look like a completely different person by stating peaceful rhetoric and showing readiness in having good relations with the highly criticized Yugoslavians. However, such attitude wouldn't last for too long as the relations would crack again according to the CIA's report on this case: "The party was strongly resisting any changes in its Stalinist practices or its relations with Yugoslavia" (CIA, 1962, p. 18).

Tito's rapprochement with the Soviets and the remaining pro-Titoist cells within the Albanian communist party provided Hoxha with great concern regarding his position at the party. It was noted that Tito played a major role in the removal of Rakosi in Hungary and Chervenkov in Bulgaria. Thus, 
Hoxha feared that Tito would as well persuade Khrushchev into replacing him as he did with the other leaders of the Eastern-Bloc. Therefore, Hoxha needed to undertake extreme measures to firstly eliminate any element which would serve as a de-stabilizer and opponent to the party. Thus, in 1955 , he banned Tuk Jakova and Bedri Spahiu from the party with the accuse of being pro-Yugoslavians (Dyrmishi, 2007), and then he proceeded with the execution of Liri Gega and her husband Dali Ndreu in 1956 for the same reason (Qilimi, 2001). The elimination of the so-called "revisionists" would guarantee that the country would not follow a change in power and that the Albanian nationalism would arise (Fevziu, 2016).

However, Moscow was informed about such events and eventually, it reacted by criticizing the execution of Gega and demanded the rehabilitation of Xoxe. Khrushchev's words were distributed in April and in May, where Suslov and Petr Pospelov (the heads of the Soviet delegation in Albania at that time) would push Hoxha to rehabilitate Xoxe "the traitor". Hoxha then would respond to Pospelov by saying that "events in the Soviet Union, as well as measures taken by other fraternal parties in the releasing of the prisoners, had provided fertile ground for anti-party conspiracies" (Griffith, 1964).

Khrushchev then tried to explain why he ordered Pospelov to "interfere" in the Albanian domestic affairs, declaring that such interference was for humanitarian purposes since the executed individual (Gega) was pregnant (Griffith, 1964). On the other hand, Gega's profile as a supporter of the Yugoslavian "revisionists", rose suspicions regarding the soviet "benevolent interference", as it could as well been seen as an action to defend a supporter of their Yugoslavian allies. Moscow's reaction would feed Hoxha's and Mehmet Shehu's fear of the Soviet support in the Yugoslavian goals of eliminating the strong opponents of the Soviet-Yugoslavian relation and opponents of Tito in particular (CIA, 1962).

After purging the party, Hoxha decided to make more explicit statements regarding his strong opposition against Yugoslavia. It was in May 1956, during the third Albanian Party Committee meeting that Hoxha would declare that there would not be any de-Stalinization of the party and surely, they would not rehabilitate Xoxe. He elaborated such a statement by saying that even though they would admit that there were made some mistakes in evaluating Yugoslavia, still the fault would remain on the Beria's gang mechanism (Lavrentyie Beria). As for Xoxe's rehab, Hoxha declared that "he received the punishment that he deserved" and also, he claimed that such a decision got the support from all the party members (CIA, 1962; Omari and Pollo, 1988).

As for Spahiu's and Jakova's expulsion, Hoxha claimed in June of the same year that both of them were trying to split the party and to put an end to the Marxist-Leninist model and they were shifting to the "nationalist, Trotskyite and national bourgeoisie tendencies" (Griffith, 1964). Moreover, such occasion would shed a light on Hoxha's opinion regarding the interference that was undertaken by the soviets, in his strong statement on that day in which he claimed that "the party was handling this matter in a spirit of Marxism-Leninism and would not tolerate any outside interference" (Griffith, 1964; CIA, 1962).

\section{China's Approaching Towards Albania}

One of the major actors in enhancing and raising firstly the discontentment of the small soviet satellite towards the new Soviet-Yugoslav approach and then secondly influencing in its foreign policy was People's Republic of China (PRC). At that time, China's influence was growing and it was the Soviet Union's greatest rival (Friedman, 2015).The rivalry was as an evidence of the differences between Mao Zedong and Khrushchev, with the former strongly disagreeing on the De-Stalinization process initiated by the latter (Marku, 2019). Therefore, the Chinese were encouraged to recruit new allies and the most adequate "potential" ally was Albania, since it was a country which was facing quite serious economic challenges. Thus, by taking advantage of the Albanian economic difficulty in 1953, the Chinese would show up as beneficiaries by offering to their potential ally a considerable amount of financial aid. Consequently, by the end of 1954, both countries would sign a small long- 
term agreement and making their partnership official (Biberaj, 1986; Mëhilli, 2017).

The Chinese government was aware that a small and underdeveloped country such as Albania would find difficulties in restructuring their economy but also in protecting themselves from an imminent threat. Therefore, by offering to the small Mediterranean country their support in such harsh times it would easily convince the Albanians to join them. This way, China had found a country through which it can access Europe, a continent which has been shielded by the USSR and Yugoslavia in the East (Hamm, 1963).

The issues which emerged between Albania and The Soviet Union in 1955 and 1956 would give a large impulse to the Chinese investments in the small satellite. In fact, from 1955 to 1956, Albania's total passive balance represented by China went from $4.2 \%$ to $17 \%$, and then in 1957 , they would reach $21.6 \%$ (Griffith, 1964).

According to Griffin, these influxes of investments deriving from China to Albania and the emerging and tightening of the relations between the two is also a product of their ideological entanglement with Stalinism which commonly opposes the Khrushchev path. These relations were solidified by a meeting held between Hoxha and Mao Zedong in 1956 in Beijing where the Chinese leader would show his support for Albania's stance on the issue of Yugoslavia and its involvement in the Hungarian Revolution of the same year and also the Polish uprisings.

The numbers given in 1957 would show nothing but China's hindered intention in actually competing The Soviet Union by laying their economic power upon on one of Moscow's patronized satellites. However, Beijing still wouldn't openly state their real intention but rather they preferred to stay into the shadows and play the role of Albania's good friend and not of Moscow's enemy. Therefore, China would remain silent, until the right time to show their true intentions would arrive.

\section{The Improvement of the Soviet-Albanian Relations}

China's growing presence in the Eastern Bloc, and especially in Albania, surely triggered a Soviet response to it. Moscow could perceive what Hoxha and his party leaders were experiencing regarding the position that Yugoslavia was taking in the bloc. Therefore, Khrushchev would, to some extent, start supporting Hoxha and the Albanian party leaders diplomatically and especially in their affairs with Yugoslavia.

As a start, Moscow would openly support Hoxha's right to criticize Tito's policy and its implication in the 1956 revolutions. Through the highly recognizable journal "Pravda", the Russian leaders would lay criticism on Tito's interference in the internal policy of Albania (Logoreci, 1977; Freedman 1970). Moreover, in April 1957, Khrushchev invited the Albanian leaders in Moscow to strengthen their relations.

Another tactic implemented by Moscow was the use of a new financial policy with its small satellite. In fact, on April $17^{\text {th }}$, the USSR would cancel the 422 million rubbles of Albania's debt and offer it a new 31 million rubbles in aid to improve its agriculture and what's more important, to end its food rationing (Griffith, 1964; O’ Donnell, 1999).

The slight change in foreign policy that Khrushchev undertook could as well be explained by the emerging of Tito's strong competition with the other small satellites. The refusal of the head of Yugoslavia to participate in the 12th party Congress in Moscow in November would irritate Khrushchev, who consequently would start a campaign of criticism against Yugoslavia. The aggravation of the situation would lead to a total exclusion of Yugoslavia from the bloc's businesses.

The aggravation of the Soviet-Yugoslavian relations would once again turn into a profitable situation for Albania as Moscow would thereafter focus on their reliable allies. Such enhanced attention would be perfectly explained by Khrushchev's visit to the city of Butrint in Albania on May $25^{\text {th }}, 1959$ (Griffith, 1964). 


\section{A Re-Emerging of the Crisis}

Even though it seemed that Khrushchev's visit in 1959 in Butrint would seal off any possible contradiction and uncertainty regarding their relation with Albania, the dynamics which occurred in 1960 would turn everything upside down. It was China's interference which would contribute to the aggravation of the situation and eventually manage to "absorb" Albania into their political influence.

It all began with the Albanian delegation's visit to Beijing in October 1959, which tighten up the countries' relation. Such an approach would turn to be quite concerning for the Soviet camp as they started to perceive that something was going on but still there was no pronouncement from Moscow (Pano, 1968; Griffith, 1964).

The year 1960 would emerge and forge all the frustrations, strong oppositions and political clashes of the main protagonists of such historical events. The first factor which surely contributed to the heating of the situation not only in Albania but also in the whole Eastern Bloc was a possible new approaching between the Soviet Union and Yugoslavia. It was an invitation for Vukmanovic-Tempo, the head of the Yugoslav trade union to come to Moscow which caused all the fuss. Such an approaching was seen with great concern by the Albanian side who consequently affected their behaviour towards Moscow (Griffith, 1964).

Consequently, during a Warsaw Pact meeting, Khrushchev would lay criticism upon China's foreign policy regarding their attitude with Yugoslavia as in fact, the Chinese leaders had an extreme reaction towards the Khrushchev's "peaceful coexistence" and his visit in September 1959 in America. Hoxha, who shared the same leftist ideology with the Chinese leadership, would eventually feel threatened and come up from the meeting quite disappointed and infuriated. The reason behind Hoxha's disappointment could be found in Khrushchev's effort into forcing Albania to change its economic policies to tackle the agricultural issues, attempts which Hoxha highly contested; According to Hoxha, the bread production was the main issue for Albania while on the other hand, the Soviet leader would say quite the opposite and even persuade the Albanians to focus more on the production of fruits as USSR had enough grain to supply the small satellite (Griffith, 1964)

Nevertheless, both Moscow and Tirana would continue to have quite peaceful relations. Such a formal and peaceful attitude would no longer continue as in fact, the problems would again emerge into the surface.

In the upcoming months, Albania's foreign policy would focus on engaging strong criticism of Yugoslavia. Such acts were surely inspired by another approaching of Tito and Khrushchev, but also by openly massive support from its newest ally, China.

The event in which would finally show Moscow's position towards the opponents of his ideology, in this case, China and Albania (implicitly), was the Bucharest meeting which was held between the $18^{\text {th }}$ and $27^{\text {th }}$ of June, 196o. On that meeting, Albania was represented by Hysni Kapo, as Enver Hoxha and Mehmet Shehu were absent perhaps since they wanted to avoid making any pronouncement on the "Chinese issue" (Omari and Pollo, 1988).

On June $21^{\text {st }}$, Khrushchev would engage in a wave of harsh criticism on China and not only. The soviet leader would read a very long letter concerning his objections and disapprovals towards China and their supporters (implying Albania). Such a letter, would directly lay upon China and indirectly upon Albania, very harsh accusations regarding a strong opposition which these two countries made to the De-Stalinization process and how such oppositions would eventually make it quite hard for such process to be fully executed in the other parties. Moreover, it would make the Chinese and presumably the Albanians guilty of the Paris Treaty's failure. The words such as "lunatics" or "maniacs", that were used to describe the Chinese and their supporters (Albania) clearly showed Khrushchev's opinion on these two countries (Hoxha, 1975).

Moreover, as Khrushchev was apparently being irritated from the decision-makings of China and proceeding with Albania implicitly, it would as well retaliate indirectly by putting threats such as cutting the economic aid and thus giving them a harsh time in the ruling of their country.

On the other side, China would undergo verbal attacks on Moscow and Yugoslavia by raising 
assumptions that in fact, Tito was serving the Americans. Surely such tactic that Beijing followed was used to ascertain its position regarding the whole bloc but also to show its very strong support to Tirana (Griffith, 1964).

However, what is interesting about this meeting is the reaction of the Albanian representative Kapo. He kept a dualistic attitude as he would show support to the USSR and China at the same time. According to Griffith, he would support the soviet initiative for peace and cooperation which, in the words of Kapo, was being challenged by the American Imperialists. In addition to that, had shown sturdiness in preserving and following their ideological streams. In this aspect, would Kapo be seen as more "liberal" and more in conformity with Moscow's ideals? However, when it came to discussing Yugoslavia, Kapo toughened his language and showed an extreme attitude where the Yugoslavs were depicted as the servant of the American Imperialists and even worse, as tools which will help spread the Imperialism (Griffith, 1964).

Besides showing such a harsh attitude, Kapo would as well object Khrushchev's way of attacking China, an action which gave to the meeting a much bitter taste and would fade away any doubt on Albanian support on China.

\section{The Soviet Pressure on Albania and the Failed Coup}

The Bucharest meeting turned up to be quite frustrating and let Moscow quite disappointed and irritated by how the Albanian representative behaved and the words that he said. Moreover, Albania would find itself between two fires which directly contributed to the alteration of the historical dynamics of that time.

In the summer of the same year, The Soviet Union together with the other Eastern-Bloc countries, would cut their economic aid to Albania as a "punishment" and perhaps as a way of putting the small satellite on the "right tracks" again. Such a decision worsened the situation in Albania as the small country began to experience severe drought and concerning food shortage. However, China's approach would turn up to be important as they declared to have bought wheat from France and started distributing it in Albania (Griffith, 1964).

The return of Kapo in Tirana after the meeting would only reaffirm Hoxha's positioning alongside China. It was on July $11^{\text {th }}$, during the Albanian Central Committee gathering that Hoxha would give a speech in which he would openly support the Chinese government to its fullest: "The plenum completely and unanimously approved the attitude maintained by the Albanian Workers Party delegations at the meeting of the representatives of Communist and workers parties, as well as the communiqué released by the meeting, held in Bucharest in June 1960" (Hoxha, 1975, pp. 38-61).

A month later, on August 13 ${ }^{\text {th }}$, Khrushchev would send a letter to the Albanian leadership in which it would invite them to discuss the initiation of the Moscow meeting in November. Hoxha knew pretty well that if he would accept Moscow's invitation then he, together with the other party members, would be under the pressure of changing their attitude not only towards The Soviet Union but they would be forced to criticize China as well. Therefore, two weeks later, Hoxha would reply to the letter by stating that these negotiations which were intended to put into criticism the ideology of Marxism-Leninism that has been endorsed by another country (implying China), were considerate a violation (Griffith, 1964). On August $27^{\text {th }}$, Moscow would send another letter to Albania to discuss the misunderstandings that occurred during the Bucharest Meetings. Having openly shown his siding with China and also his criticism of the Soviet Union, Hoxha decided to not reply to the letter (AQSH, 1960).

Hoxha's refusal of the Soviet invitation would push Khrushchev to organize a coup against the Albanian party leader. Luckily for Hoxha, such an attempt didn't work and, according to him, the coup was organized through the cooperation between Moscow and pro-soviet cells within Albania, more specifically Liri Belishova and Koço Tashko. Also, from the document retrieved by the Greek officials of that time, part of the coup was vice-admiral Sejko, the commander of the Albanian naval forces together with three other generals. 
Consequently, on September $4^{\text {th }}$, both Belishova and Tashko would be removed from the party and probably arrested and imprisoned together with Sejko, as it was expected to happen in such situations (CIA, 1962; Fevziu, 2016).

\section{The Moscow Conference}

After the failed coup upon the Albanian leader, the situation would deteriorate even more with the sudden suspension of the wheat product to Albania, which was organized by Moscow. Consequently, the ties between Albania and China would tighten even more, as it would be affirmed by the Albanian representative in the International Meeting of Communist and Workers Parties in Moscow, or otherwise known as the "Moscow conference".

Days before the opening of the conference, Khrushchev would come up with a long letter in which he would criticize Albania for allying with China and for taking anti-Soviet actions. This letter would precede the meeting that occurred on November $12^{\text {th }} 1960$, in which the Albanian leadership composed of Enver Hoxha, Mehmet Shehu, Hysni Kapo and Ramiz Alija, would engage a debate with Khrushchev regarding the letter and issues which were of great concern to them.

During this meeting, they would discuss Albania's sudden change of attitude towards The Soviet Union; Enver Hoxha would bring up that firstly they had disagreements relating to the Yugoslavs and that the change of attitude would come after the Bucharest meeting in June in which Khrushchev criticized the Albanians. On the other side, Khrushchev would keep a steady position and claimed to not have been aware of this disagreement and as for the Bucharest meeting, he would express that the criticisms weren't purposely put to worsen the relations between the countries (AQSH, 1960). Furthermore, Hoxha would continue by blaming the soviets for the worsening of the relations and that he had facts that would prove such accusation. Then the debate would be about who would carry the fault of the whole events that had occurred. Hoxha cited a part of Khrushchev's letter in which the Albanian party leaders were accused of "expelling the other party members in an undemocratic way and also that their expel was due to their pro-soviet stands", and thus making Hoxha and other party leaders seem as anti-soviets (Hoxha, 1975, pp. 519-520). Khrushchev would stick to this assumption and also, he would add that such actions made by Hoxha were bad for their relations (AQSH, 1960). The debate then would concentrate on a very important issue such as the proposal of Moscow to remove the military base in Vlora, located in south Albania (AQSH, 1960, pp. 32-33); According to the records, such proposal would be more of a reaction towards Hoxha's actions rather than a pre-organized plan, as stated in the letter, Hoxha would declare that Khrushchev was not a Marxist even though according to the soviet side it was him who granted Hoxha the approval to build the military base while Stalin would refuse to do it. Later on, Hoxha would again bring up the argument that the deterioration of the relations occurred only after the Bucharest pact and again, he would criticize the soviets for their bad temper. Khrushchev then would use Hoxha's argument to turn it against him by claiming that if he would continue having such a bad temper, then it would be impossible for the discussions to continue (Griffith, 1964). Such a statement would infuriate the Albanian leader which would eventually make them say that they would not "agree to continue talks under these conditions" and that "Albania would always remain faithful to the Soviet Union and be a member of the socialist camp" (Griffith, 1964). After this declaration, the Albanian delegation would leave the room.

However, 4 days after their meeting, Hoxha would make a damning speech in which he would verbally attack Khrushchev. In his speech, Hoxha would strongly criticize Khrushchev for accusing China and for forcing the other parties of the bloc to join the soviets in the accusations. Another concerning issue for Hoxha was surely Yugoslavia and specifically Khrushchev 's visit in Belgrade in 1955; A visit which, according to Hoxha, the Albanians weren't informed about. Hoxha then would mention the counterrevolution in Hungary as Khrushchev's wrongful decision (Griffith, 1964; AQSH, 1960, pp. 3-12). Moreover, according to Hoxha, the soviets would rely on Tito even though they were aware of his intentions on Albania and Hungary. The speech continued by explaining how the letter 
that Khrushchev sent in August 1960 in which he expressed his desire for Albania to join him in his attacks on China, would make him and his party leaders seem as "fractionalists" (Hoxha, 1975, pp. 56) Later on, the speech would turn to be quite dramatic as Hoxha would describe the very difficult situation which Albania was experiencing after Moscow decided to stop furnishing the small satellite with wheat: "Albania has suffered earthquakes, floods, and droughts of 120 days and has been threatened by famine. Only 15 days' supply of wheat remained in the stock. After a delay of 45 days, the USSR promised us 10,00o tons of wheat to be delivered in September or in October. These are unbearable pressures. The soviet rats were able to eat whilst the Albanian people were dying of hunger; we were asked to produce gold" (Hoxha, 1975, pp. 451-452).

Despite the arguments that Hoxha used in his speech, he was widely criticized by all the soviet supporters, especially by the Spanish communist leader and by Janos Kadar. The only supporters of such speech would be China and probably North Vietnam and North Korea.

\section{The Final Split}

Hoxha's last meeting in Moscow would enhance a further deterioration of the Albanian-Soviet relations which would lead to the final split by the end of 1961.

A couple of months after the Moscow conference, the Albanian party leaders would require further assistance from the soviets to build the Palace of Culture in Tirana. However, Moscow did not reply to such a request until the $12^{\text {th }}$ of April, which surely was already too late. Besides this episode, another "crack" such as the retrieving of the soviet's oil specialist would come up (Griffith, 1964).

On February $20^{\text {th }}$, Hoxha would invite the soviet delegation (Peter Pospelov, Yuri Andropov and Josif Shikin) to the Albanian Party Congress, where he would provide to the delegates his major concerns. The records show that the meeting was full of tension which was pumped up by Hoxha's verbal attacks towards the soviet presence in the country and specifically of their deployed specialists in the geology and maritime sectors. On the other hand, the delegates expressed their discontent on such negative reaction by the Albanian side and laid a warning that such attitude would not only disrupt the current Albanian-Soviet relation but it would impact the whole socialist bloc and if there is no remedy to such behaviours then the ramifications will be heavy (AQSH, 1961, pp. 2-26).

The deterioration of the relations would continue with the Soviets' response regarding the provision of aid for the construction of the Palace of Culture. From the declarations made by both sides in April $23^{\text {rd }} 1961$, the soviets would retrieve the ships containing the materials needed for the construction of the Palace of Culture, which, according to Moscow, happened due to the behaviour and pressure made by the Albanian leaders on the Soviet delegation (Griffith, 1964).

Later on, the soviets would come up with a letter written by Alexei Kosygin (the soviet first deputy) in which he first would put the future of the Albanian-Soviet relations into question and then he would explain the decision on retrieving the shipping of the materials in relation with the situation:

After weighing all the circumstances, the Soviet Government is obliged to re-examine the question of future relations with the Albanian People's Republic...The Soviet people and the peoples of other socialist countries would not understand us if, we while depriving our country of material resources, should continue to satisfy the demands of the Albanian leaders who, to the determinant of the interests of the Albanian people, have trampled on elementary norms in relations with the USSR and its government...Understandably, the Albanian leadership cannot expect in the future that the USSR will help it as it has in the past, with aid from which only true friends and brothers have the right to benefit. The Soviet Union deems it necessary henceforth to establish its relations with Albania on a new basis taking into account the unfriendly policy of its leadership toward the Soviet Union and the other socialist countries...As concerns to future relations between our countries, and USSR aid to Albania, these will depend entirely on the attitude adopted by the Albanian party (Freedman, 1970, $p$. 79; Ash, 1974, p. 205). 
The crisis within Soviet-Albanian relations would become more evident during the Warsaw Council Committee in March in which the Albanian leaders weren't invited and in which, it was decided that the Soviet Union would withdraw its naval base in Vlora by retrieving ships and 8 (eight) submarines (ISML, 1981). Such decision was followed by attempts from the Albanian government to stop the Soviet Ships from sailing away and intense letter exchanges between the Albanian Minister of Interior Beqir Balluku and the Commander-in-Chief of the Warsaw Pact Forces (Hoxha, 1977).

The use of harsh language and the showcasing of a rebellious behaviour by the Albanian side pushed Moscow into breaking with Tirana regarding the granting of soviet loans on April $26^{\text {th }} 1961$. Such decision was taken after several warnings that were sent to the Albanian party officials to change the attitude as they would face severe consequences. However, Hoxha remained quite consistent in his defiant behaviour knowing quite well that he was playing with fire.

Consequently, from the $2^{\text {nd }}$ to the $5^{\text {th }}$ of August 1961, during a meeting held in Moscow between the Secretaries of the Warsaw Pact's member states, in which the Albanian delegation was represented by Ramiz Alia was characterized by certain inconveniences. Some of the representatives at that meeting claimed that the Albanian delegation was being represented by Alia against the protocols envisaged by the Warsaw Pact, and for that reason, it was proposed to forbid the Albanian delegation from attending such meeting.

The proposal was badly received by Hoxha who condemned it during the Meeting of the Albanian Politburo, held on August $7^{\text {th }} 1961$ (AQSH, 1961).

The culmination of Soviet Union's harsh measures taken on Albania would arrive during the ${ }_{22}{ }^{\text {nd }}$ Communist Party Congress of the Soviet Union, held in Moscow. During that congress, Khrushchev would lay several attacks upon the Albanian party leaders by bringing up the case of Gega, the woman which was executed by Hoxha and the expulsion of Belishova and Tashko from the party. Later on, Khrushchev would use words such as "fractionist" or "sectarist" to describe the philosophy of the Albanian party leader. Moreover, Mikoyan would claim that through their ideology, the Albanian would cause "the enragement of the Marxism-Leninism and from the socialist camp and World Communist movement". Khrushchev would go even further by requesting the punishment for such acts and also stating that the support from the other eastern bloc countries would signify that they were aware of the abnormal Soviet-Albanian relations. Therefore, Khrushchev publicly announced the disruption of the relations between the Soviet Union and Albania (Griffith, 1964).

Later on, during the Albanian Politburo meeting, Hoxha would respond to Khrushchev's speech by using very harsh words, showing a pretty much extreme ideology. He, together with the other party leaders, would call Khrushchev an "anti-Marxist", or even a "putschist", implying that the Soviet leader was a traitor. Hoxha then would point out their strong support to China, the strong bond with the Stalinist ideology, and their strong opposition to the imperialists (Hoxha, 1977).

Moreover, the Albanian heads of state would order their embassy in Moscow on November $2 \mathrm{O}^{\text {th }}$ 1961, to distribute a letter to the whole Eastern Bloc countries in which it would explain the economic and historical background of Albania and its complex relations with the Soviet Union. Such letter was sent after other countries of the Warsaw Pact would break all the economic agreement that they head and cut diplomatic ties with Albania (Griffith, 1964).

On the same month, the Soviet Union 's Ministry of Foreign affairs notified the Albanian envoy in Moscow that they are requesting to withdraw their diplomatic personnel in Tirana and thus, applying the "diplomatic split" from each other with the justification that the Albanian state had harassed the soviet diplomats and that they demanded a shortage of their representative in Tirana (Smirnova, 2004).

As a result of that, in 1962, Albania would break away even from COMECON after being completely isolated and disregarded from the member states and in 1968, from the Warsaw Pact.

Consequently, Albania carried out its close relationship with China up until 1978, when the latter would withdraw all the trade agreements and cut the economic and diplomatic ties with the former due to the disputes that emerged between them in the period 1972-1978 (Biberaj, 1986; 
Mëhilli, 2017).

\section{1o. Conclusions}

Regardless of its territorial size and geopolitical importance in the region of Eastern Europe, Albania, through its leadership, played all the cards in the deck to preserve its status quo. The decisions taken by Hoxha were seen to be taken from a rational choice-making prism where the political survival was at the most utmost importance. Such thing was seen with Hoxha's ambiguity in behaving towards Khrushchev's decisions, especially regarding Yugoslavia. At that time, Yugoslavia was a regional power and had the liberty and the capacity on making demands even on a great power such as the Soviet Union. Each time these two states would dispute, Albania would find itself in a comfortable position by supporting the Soviet Union who did not have much interest in its territory. However, when the Yugoslav-Soviet relations improved and when it was seen that the leaders in the Eastern Bloc were being changed and that Yugoslavia was involved in such process, Hoxha decided to find comfort in China.

China was an emerging power and was trying to lay its influence in Europe and oppose the Soviet Union. In that sense, Albania became the only gate through which they could enter into the old continent. On the other hand, Albania needed more financial and technical assistance and also for protection from a possible annexation from Yugoslavia or an attack from the Soviet Union. This dichotomy of interests wasn't left unnoticed by the Soviet Union immediately expressed its discontent by verbally attacking both of the countries.

Eventually, the Albanian-Soviet relations would further continue to aggravate until they reached the tipping point during and after the Moscow conference. Khrushchev was fed up with Hoxha's rebellious behaviour through the purges that he conducted in its country and also with his flirting with China. In light of such a situation, Khrushchev would take drastic measures in withdrawing its military and financial support to Albania and eventually seize any diplomatic relations. Consequently, Albania became the second country to split away from the Soviet Union after Yugoslavia and one of the most isolated countries in the world after it brokered the relations with China as well afterwards.

\section{References}

AQSH. (1960), F.14. D. 21, fl.7. Tirana.

AQSH. (1961), Records of the meeting held between Enver hoxha and the Soviet Delegates who were invited to participate in the Albanian Party Congress on February 20 th 1961.

AQSH. (1961), Traktati i Varshavës, Tirana.

Ash, W. (1974), Pickaxe and Rifle: The Story of the Albanian People, London: Howard Baker Press Ltd.

Biberaj, E. (1986), Albania and China: A Study of an Unequal Alliance, Boulde, CO: Westview Press.

CIA (1962), Current Intelligence Staff Study: Soviet-Albanian relations 1940-196o.

Dyrmishi, D. (2007), Goditjet e organeve të drejtësisë dhe dënimi i Tuk Jakovës dhe Bedri Spahiut (1949-1952), Studime Historike (o1-02), pp. 102-113.

Fevziu, B. (2016), Enver Hoxha: The Iron Fist of Albania, London: I.B.Tauris.

Fischer, B. J. (2007), Enver Hoxha and the Stalinist Dictatorship in Albania, in B. J. Fischer, Balkan Strongmen: Dictators and Authoritarian Rulers of Southeast Europe, West Lafayette, IN: Purdue University Press, pp. $239-68$.

Freedman, R. O. (1970), Economic Warfare in the Communist Bloc: A Study of the Soviet Economic Pressure Against Yugoslavia, Albania and Communist China, New York: Praeger Publishers.

Friedman, J. (2015), Shadow Cold War: The Sino-Soviet Competition for the Third World, Chapel Hill: University of North Carolina Press, 2015.

Griffith, W. E. (1964), Albania and the Sino-Soviet Rift, Massachusetts: The MIT Press.

Hamm, H. (1963), Albania-China's Beachhead in Europe, New York: Praeger.

Hoxha, E. (1975), Fjala e mbajtur në emër të KQ-së së PPSH-së në Mbledhjen e 81 PK-ve dhe PP-ve në Moskë, në nëntor 196o, Tirana: Instituti i Studimeve Marksiste e Leniniste. 
Hoxha, E. (1975), Vepra 19, Tirana: 8 Nëntori.

Hoxha, E. (1977), Vepra 21, Tirana: 8 Nëntori.

Hoxha, E. (1986), Artful Albanian: The Memoirs of Enver Hoxha, (J. Halliday, Ed.), London: Chatto \& Windus.

ISML. (1981), Historia e Partisë së Punës të Shqipërisë, Tirana: 8 Nëntori.

Kramer, M. (2014), Stalin, The Split with Yugoslavia, and Soviet-East European Efforts to Reassert Control, 19481953, in T. Snyder, \& R. Brandon (eds.), Stalin and Europe: Imitation and Domination, New York: Oxford University Press, pp. 295-315.

Logoreci, A. (1977), The Albanians: Europe's Forgotten Survivors, London: Victor Gollancz Ltd.

Marku, Y. (2019), Communist Relations in Crisis: The End of SovietAlbanian Relations, and the Sino-Soviet Split, The International History Review, pp. 1-20.

Mëhilli, E. (2017), From Stalin to Mao: Albania and the Socialist World, New York: Cornell University Press. O'Donnell, J. S. (1999), A Coming of Age: Albania under Enver Hoxha, New York: Columbia University Press.

Omari, L. and Pollo, S. (1988), The History of the Socialist Construction of Albania, Tirana: 8 Nëntori.

Pano, N. C. (1968), People's Republic of Albania, Baltimore, MD: The Johns Hopkins Press.

Pipa, A. (1990), Albanian Stalinism: Ideo-Political Aspects, New York: Columbia University Press.

Qilimi, M. (2001, February 11), I dënuam me vdekje Dali Ndreun dhe Liri Gegën që t'i falte më pas Enveri: (D. Kaloçi, Interviewer), Gazeta Shqiptare.

Smirnova, N. (2004), Historia e Shqipërisë pèr mes shek. XX, Tirana: Ideart. 